\title{
Physicochemical properties and storage stability of blueberry fermented by lactic acid bacteria
}

\author{
Dae-Hoon Lee, Joo-Heon Hong* \\ Department of Food Science and Technology, Catholic University of Daegu, Gyeongsan 38430, Korea
}

블루베리 유산균 발효물의 이화학적 특성 및 저장안정성

\author{
이대훈·홍주헌* \\ 대구가톨릭대학교 식품공학전공
}

\begin{abstract}
The physicochemical properties and storage stability of blueberies fermented by lactic acid bacteria were investigated. The viable cell count of lactic acid bacteria slowly increased to $5.96 \log$ CFU $/ \mathrm{mL}$ after $72 \mathrm{hr}$ of fermentation. The $\mathbf{p H}$ decreased whereas titratable acidity increased after fermentation. The contents of total anthocyanin (31.52 $\mathrm{mg} / 100 \mathrm{~g})$ and cyanidin-3-glucoside (C3G) $(5.41 \mathrm{mg} / 100 \mathrm{~g})$ after $72 \mathrm{hr}$ of fermentation were higher than those of non-fermented blueberies $(16.10 \mathrm{mg} / 100 \mathrm{~g}$ and $2.21 \mathrm{mg} / 100 \mathrm{~g}$, respectively). The $\mathrm{L}$ and a value decreased, and the $\mathbf{b}$ and $\triangle \mathbf{E}$ value increased. The total polyphenol and flavonoid contents of fermented blueberies (2.21 $\mathrm{g} / 100 \mathrm{~g}$ and $0.91 \mathrm{~g} / 100 \mathrm{~g}$, respectively) were higher than those of non-fermented blueberies $(1.13 \mathrm{~g} / 100 \mathrm{~g}$ and $0.49 \mathrm{~g} / 100 \mathrm{~g}$, respectively). The DPPH radical scavenging activity and superoxide radical scavenging activity of the fermented blueberies were $30.74 \%$, and $52.76 \%$, respectively. The ferric reducing antioxidant power of the fermented blueberies $(256.42 \mu \mathrm{M} / \mathrm{g})$ was higher than that of non-fermented bluebenies $(191.52 \mu \mathrm{M} / \mathrm{g})$. Anthocyanin and C3G content was stable in fermented blueberies after 42 days of storage. The results suggest that blueberies fermented by lactic acid bacteria have the potential to be functional materials in the food industry.
\end{abstract}

Key words : blueberry, fermentation, anthocyanin, physicochemical properties, storage stability

\section{서 론}

최근 소비자들의 합성색소에 대한 인식 변화와 사용규제 강화에 따라 생물자원으로부터 천연 식용색소의 탐색에 대한 많은 연구가 진행되고 있다(1). 특히 식품에 이용되는 천연색소는 합성색소에 비해 발색, 안정성 및 가격경쟁력 등에서 뒤떨어져 이용률이 낮았으나, 최근 천연색소의 안 정성 및 다양한 효능이 보고됨에 따라 소비자의 관심이 증대되고 있다(2).

천연색소 중 안토시아닌은 각종 식물의 잎, 꽃 및 과실

*Corresponding author. E-mail : jhhong@cu.ac.kr

Phone : 82-53-850-3218, Fax : 82-53-850-3218

Received 18 September 2015; Revised 1 October 2015; Accepted 6 October 2015.

Copyright (c) The Korean Society of Food Preservation. All rights reserved.
등에서 적색에서 청색에 이르는 다양한 색을 발현하는 색소 이다. 식물에서 600 종 이상이 발견되고 있는 안토시아닌은 모두 안토시아니딘 배당체로서 flavilium(2-phenylbenzopyrilim) 의 기본 구조에 수산기 또는 메톡시기가 치환되어있는 구조 를 가지며(3), cyanidin계의 고유의 색을 지닌 chrysanthemine 으로 물에 쉽게 용해되는 수용성이므로 천연 식용색소로의 이용가능성이 매우 높다 $(4,5)$. 최근 안토시아닌 색소는 천 연 식품 첨가제로서의 기능성과 함께 기능성 물질로서의 역할에 관한 연구가 이루어지고 있으며, 안토시아닌의 대 표적인 색소인 cyanidin-3-glucoside는 산화적인 스트레스 에 강한 것으로 보고됨에 따라 항산화 및 항암 등에 효과가 있는 것으로 알려져 있다 $(6,7)$

블루베리는 쌍떡잎식물인 진달래과(Ericaceae) 산앵두 나무속(Vaccinium)에 속하는 관목성 식물로서 약 400여종 이 있으며(8), 뛰어난 생체 조절 기능성을 갖는 생리활성 화합물들을 함유하고 있어 각종 성인병 예방에 효과적이라 
는 사실들이 밝혀지고 있다(9). 최근 국내에서도 블루베리 에 대한 관심이 높아져 냉동생과, 잼, 와인 및 소스 등으로 가공되고 있고, 제과 원료로도 폭넓게 이용되고 있다(10). 블루베리 성숙과실에는 다양한 영양성분들과 기능성 물질 인 안토시아닌 및 레스베라트롤 등이 다량 함유되어 있으 며, 특히 피토케미컬이 풍부하여 활성산소를 억제하는 항 산화 작용과 노화방지 및 질병예방에 효능이 있는 것으로 보고되고 있다(11). 그러나 안토시아닌은 다른 색소 성분에 비해 구조적으로 전자가 1개 부족한 oxonium 화합물로 다 양한 가공 및 저장조건에서 가장 불안정한 것으로 알려져 있어 식품가공용으로 이용하기에 많은 제약을 갖고 있다 (12).

한편, 유산균은 인간이 이용할 수 있는 가장 유익한 미생 물의 한 종류로서 300 400여 종이 있는 것으로 알려져 있다 (13). 유산균의 주요 대사물질인 lactic acid는 $\mathrm{pH}$ 의 저하 및 보존성을 향상시킴으로써 미생물의 생육을 억제하고 항균작용을 나타내며, 대표적인 probiotics 소재로 다양한 식품에 활용되고 있다.

따라서, 본 연구에서는 블루베리의 식품 산업에서의 이 용 증대의 일환으로 블루베리 분쇄물을 유산균을 이용하여 발효하였으며 발효물의 이화학적 특성 및 저장 안전성을 조사하였다.

\section{재료 및 방법}

\section{실험재료}

실험재료는 미국산 블루베리(Firestone Pacific Foods, Vancouver, WA, USA)를 냉동 상태로 구입하여 $-20^{\circ} \mathrm{C}$ 에 보관하면서 본 실험에 사용하였다. 시료는 분쇄기(FM909 W, Hanil Co., Sejong, Korea)로 분쇄한 다음 autoclave (HB-506-4, Hanbaek Science Co., Bucheon, Korea)를 이용하 여 $121^{\circ} \mathrm{C}$ 에서 15 분간 멸균 시킨 후 실험에 사용하였다.

\section{발효물 제조}

블루베리 발효물 제조를 위하여 사용된 균주는 김치에서 분리하여 대구가톨릭대학교 식품공학전공 기능성식품연 구실에서 보관중인 Lactobacillus plantarum CGKW3 (KACC92075P) 균주를 MRS broth(Difico Co., Detroit, MI, USA)배지에 24 시간 전 배양한 다음, 배양액 $2 \%(\mathrm{v} / \mathrm{v})$ 를 멸균된 블루베리 분쇄물에 접종하고 $37^{\circ} \mathrm{C}$ 에서 0 96시간 정치 배양(IL-21, Jeio tech., Daejeon, Korea)하였다. 배양이 완료된 배양액은 원심분리기(VS-6000CFN, Vison Co., Daejeon, Korea)를 이용하여 $3,000 \mathrm{rpm}$ 에서 10 분 동안 분리 한 다음 상등액을 동결건조(FreeZone 2.5, Labconco Co., Kansas, MO, USA)하여 $-70^{\circ} \mathrm{C}$ 이하에 보관하면서 분석용 시료로 사용하였다.
생균수, $\mathrm{pH}$ 및 산도

생균수 측정은 배양액을 1 분 동안 균질화 시킨 다음 1 $\mathrm{mL}$ 를 취해 MRS agar(Difico Co.)배지를 사용하여, $37^{\circ} \mathrm{C}$ 에 서 24시간 배양한 다음 형성된 colony 수를 계측하고 희석 배수를 곱하여 나타내었다. $\mathrm{pH}$ 측정은 $\mathrm{pH} \operatorname{meter}(\mathrm{CH}-8603$, Mettler toledo Instruments Ltd., Langacher, Switzerland)를 이용하여 배양액 $20 \mathrm{~mL}$ 를 취하여 3 회 반복 측정하였다. 또한 총 산도는 $0.1 \mathrm{~N} \mathrm{NaOH}$ 를 $\mathrm{pH}$ 가 8.3이 될 때 까지 적정 하였으며 적정에 소비되는 $0.1 \mathrm{~N} \mathrm{NaOH}$ 용액의 소비량을 유기산함량으로 환산하여 표시하였다.

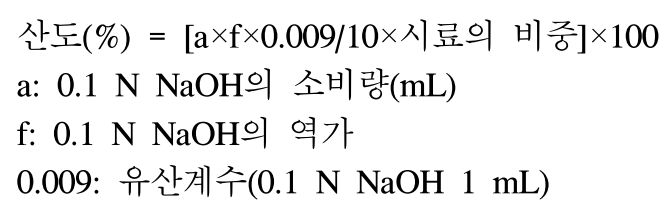

\section{총 안토시아닌 및 cyandin-3-glucoside 함량}

총 안토시아닌 함량은 블루베리를 배양 시간별로 동결 건조한 다음 Lee 등(14)의 방법에 따라 시료 $0.1 \mathrm{~g}$ 에 $\mathrm{pH}$ 1.0 buffer $(0.2 \mathrm{M}$ potassium chloride $+0.2 \mathrm{M}$ hydrochloric acid) 또는 $\mathrm{pH}$ 4.5(0.2 $\mathrm{M}$ potassium phosphate $+0.1 \mathrm{M}$ citric acid) $2 \mathrm{~mL}$ 를 각각 혼합한 다음 분광광도계(Ultraspec 2100pro, Biochrom Ltd., Cambridge, UK)를 이용하여 $520 \mathrm{~nm}$ 와 700 $\mathrm{nm}$ 에서 흡광도를 측정하였다. 총 안토시아닌 함량은 아래 와 같이 cyanidin-3-glucoside(C3G)를 기준으로 계산하였다.

Total anthocyanin content $(\mathrm{mg} / 100 \mathrm{~g})=$

$$
\begin{aligned}
& \frac{A \times M W \times D F \times 1,000}{\epsilon \times 1} \\
& \mathrm{~A}=\left(\mathrm{A}_{\lambda 520}-\mathrm{A}_{\lambda 700}\right)_{\mathrm{pH}} 1.0-\left(\mathrm{A}_{\lambda 520}-\mathrm{A}_{\lambda 700}\right)_{\mathrm{pH}} 4.5 \\
& \mathrm{MW}=\text { molecular weight of cyanidin-3-glucoside }=449.2 \mathrm{~g} / \mathrm{mol} \\
& \mathrm{DF}=\text { dilution factor } \\
& \varepsilon=\text { the molar absorptivity }=26,900 \mathrm{~L} / \mathrm{cm} \cdot \mathrm{mol}
\end{aligned}
$$

C3G 함량은 블루베리 발효물을 배양 시간별로 동결 건 조한 다음 HPLC(Waters 2695, Waters Co., Miliford, MA, USA)로 분석하였다. Column은 XBridge ${ }^{\mathrm{TM}} \mathrm{C}_{18}(5 \mu \mathrm{m}$ 4.6×150 $\mathrm{mm}$, Waters Co.)을 사용하였고 온도는 $30^{\circ} \mathrm{C}$ 였으며, 검출기 는 photodiode array detector(Waters 2996, Waters Co.)로 파장은 $535 \mathrm{~nm}$ 에서 검출하였다. 이동상 용매로 $\mathrm{A}$ 는 water: $\mathrm{HCOOH}(90: 10, \mathrm{v} / \mathrm{v}), \mathrm{B}$ 는 acetonitrile:methanol:water: $\mathrm{HCOOH}(22.5: 22.5: 40: 10, \mathrm{v} / \mathrm{v})$ 를 사용하여 $1.0 \mathrm{~mL} / \mathrm{min}$ 의 속 도로 $10 \mu \mathrm{L}$ 를 주입하였다. 표준물질은 $\mathrm{C} 3 \mathrm{G}$ (Sigma-Aldrich Co., St. Louis, MO, USA)를 HPLC chromatogram에서 retention time의 비교로 동정하였으며, peak area의 실측치 와 표준물질의 농도간 계산에 의해 함량을 계산하였다. 


\section{색도 측정}

색도 측정은 블루베리 발효물 동결건조 분말을 페트리디 쉬에 담아 표준색도가 $\mathrm{Y}=94.5, \mathrm{a}=0.18, \mathrm{~b}=0.32$ 로 보정된 색차계(CR300, Minolta Co., Osaka, Japan)를 사용하여, 밝 기를 나타내는 L(lightness), 적색도를 나타내는 a(redness), 황색도를 나타내는 $\mathrm{b}$ (yellowness)값을 측정하였으며, 색차 $\triangle \mathrm{E}$ 는 아래와 같이 계산하였다.

$$
\begin{aligned}
& \Delta \mathrm{E}=\sqrt{\left(L_{i}-L_{t}\right)^{2}+\left(a_{i}-a_{t}\right)^{2}+\left(b_{i}-b_{t}\right)^{2}} \\
& \mathrm{~L}_{\mathrm{i}}=\text { intial } \\
& \mathrm{L}_{\mathrm{t}}=\text { test }
\end{aligned}
$$

\section{총 폴리페놀 함량}

총 폴리페놀 함량은 Folin-Denis법(15)에 따라 시료 $1 \mathrm{~mL}$ 에 $1 \mathrm{~N}$ Folin Ciocalteu reagent $1 \mathrm{~mL}$ 를 혼합하여 반응 시킨 후 $20 \%$ sodium carbonate $1 \mathrm{~mL}$ 를 첨가하고 실온의 암소에 서 30 분간 반응시킨 다음 분광광도계를 이용하여 $725 \mathrm{~nm}$ 에 서 흡광도를 측정하였다. 총 폴리페놀 함량은 tannic acid를 정량하여 작성한 표준곡선으로부터 계산하였다.

\section{총 플라보노이드 함량}

총 플라보노이드 함량 측정은 Davis 등(16)의 방법을 응 용하여 측정하였다. 시료 $1 \mathrm{~mL}$ 에 $5 \%$ sodium nitrite 150 $\mu \mathrm{L}$ 를 혼합하여 실온에서 6 분간 반응 시킨 후 $10 \%$ aluminium chloride $300 \mu \mathrm{L}$ 를 첨가하고 실온에서 5 분간 반 응 시킨 다음 $1 \mathrm{~N} \mathrm{NaOH} 1 \mathrm{~mL}$ 와 혼합한 후 분광광도계를 이용하여 $510 \mathrm{~nm}$ 에서 흡광도를 측정하였다. 총 플라보노이 드 함량은 rutin을 정량하여 작성한 표준곡선으로부터 계산 하였다.

\section{DPPH radical 소거활성}

DPPH radical 소거활성은 1,1-diphenyl-2-picrylhydrazyl $(\mathrm{DPPH})$ 의 환원력을 이용하여 측정하였다(17). 즉, 시료 0.5 $\mathrm{mL}$ 에 $4 \times 10^{-4} \mathrm{M}$ DPPH용액(99.9\% ethyl alcohol에 용해) 5 $\mathrm{mL}$ 를 혼합하여 실온에서 15 분간 반응 시킨 다음 분광광도 계를 이용하여 $517 \mathrm{~nm}$ 에서 흡광도를 측정하였다. $\mathrm{DPPH}$ radical 소거활성은 블루베리 발효물의 첨가 전과 후의 차이 를 아래와 같이 백분율로 나타내었다.

$$
\begin{gathered}
\text { DPPH radical scavenging activity }(\%)= \\
\left(1-\frac{\text { sample absorbance }}{\text { controlabsorbance }}\right) \times 100
\end{gathered}
$$

\section{Superoxide radical 소거활성}

Superoxide radical 소거 활성은 Nishikimi(18)의 방법에 따라 다음과 같이 측정하였다. 시료 $500 \mu \mathrm{L}$ 에 $0.1 \mathrm{M}$ Tris- $\mathrm{HCl}$ 완충용액(pH 8.5) $100 \mu \mathrm{L}, 100 \mu \mathrm{M}$ phenazine
methosulfate(PMS, Sigma-Aldrich Co.) $200 \mu \mathrm{L}$ 를 혼합하여 반응 시킨 후 $500 \mu \mathrm{M}$ nitro blue tetrazolium(NBT, SigmaAldrich Co.) $200 \mu \mathrm{L}$ 및 $500 \mu \mathrm{M}$ ß-nicotinamise adenine dinucleotide(NADH, Sigma-Aldrich Co.) $400 \mu \mathrm{L}$ 를 첨가하여 실온에서 10 분간 반응시킨 다음 분광광도계를 이용하여 $560 \mathrm{~nm}$ 에서 흡광도를 측정하였다. Superoxide radical 소거 활성은 블루베리 발효물의 첨가 전과 후의 차이를 아래와 같이 백분율로 나타내었다.

Superoxide radical scavenging activity $(\%)=$

$$
\left(1-\frac{\text { sample absorbance }}{\text { control absorbance }}\right) \times 100
$$

\section{FRAP(ferric reducing antioxidant power)}

FRAP 측정은 Benzie와 Strain(19)의 방법에 따라 다음과 같이 측정하였다. FRAP reagent는 $25 \mathrm{~mL}$ acetate buffer(300 $\mathrm{mM}, \mathrm{pH} 3.6$ )를 $37^{\circ} \mathrm{C}$ 에서 가온한 후, $40 \mathrm{mM}$ hydrochloric acid에 용해한 $10 \mathrm{mM}$ 2,4,6-tris (2-pyridyl)-s-triazine(TPTZ) $2.5 \mathrm{~mL}$ 와 $20 \mathrm{mM}$ ferric chloride $2.5 \mathrm{~mL}$ 를 첨가하여 제조하 였다. 시료 $30 \mu \mathrm{L}$ 에 제조된 FRAP reagent $900 \mu \mathrm{L}$ 와 증류수 $90 \mu \mathrm{L}$ 를 넣은 후 $37^{\circ} \mathrm{C}$ 에서 10 분간 반응시킨 다음 분광광도 계를 이용하여 $510 \mathrm{~nm}$ 에서 흡광도를 측정하였다. FRAP는 $\mathrm{FeSO}_{4} \cdot 7 \mathrm{H}_{2} \mathrm{O}$ 을 정량하여 작성한 표준곡선으로부터 계산하 였다.

\section{저장 안정성 분석}

블루베리 발효물에 함유되어있는 안토시아닌의 저장기 간에 따른 안정성은 발효물 동결건조 분말을 실온의 데시케 이터(ø240, lklab Co., Namyangju, Korea)에 42일간 저장하 면서 총 안토시아닌 및 cyanidin-3-glucoside 함량을 측정하 였다.

\section{통계 처리}

실험결과는 3회 반복으로 행하여 평균표준편차로 나타 내었으며 IBM SPSS Statistics(19.0, IBM Corp., Armonk, $\mathrm{NY}, \mathrm{USA})$ 를 이용하여 분산분석(ANOVA)을 실시하였으 며, 각 측정 평균값의 유의성 $(\mathrm{p}<0.05)$ 은 Duncan's multiple range test로 검정하였다.

\section{결과 및 고찰}

\section{생균수, $\mathrm{pH}$ 및 산도}

블루베리의 발효에 따른 유산균의 생육 변화를 확인하기 위하여 배양시간별 생균수, $\mathrm{pH}$ 및 산도를 Table 1에 나타내 었다. 블루베리 발효물의 배양 시간별 생균수는 72 시간까 지 $5.96 \log \mathrm{CFU} / \mathrm{mL}$ 로 가장 높은 생균수를 나타낸 다음 
96시간부터 $5.92 \log \mathrm{CFU} / \mathrm{mL}$ 로 감소하는 경향을 나타내었 다. 이는 인체에 유익한 물질들을 생성하기 위해서는 최소 한 프로바이오틱 미생물 개체수가 $10^{5} \mathrm{CFU} / \mathrm{mL}$ 이상이어야 한다고 보고되어 있어(20), 블루베리 유산균 발효에 의해 유익한 물질들이 생성 될 것으로 사료된다. $\mathrm{pH}$ 및 산도는 유산균 배양 96 시간 이 후 각각 $\mathrm{pH} 3.29$ 및 $0.21 \%$ 를 나타내 어 배양 전 $\mathrm{pH} 4.19$ 및 $0.12 \%$ 에 비해 유의적인 감소 및 증가하는 경향을 나타내었다. $\mathrm{pH}$ 의 감소 및 산도의 증가는 유산균 배양에 의해 생성된 유기산과 미생물의 유기물 분해 시 발생하는 적은 양의 옥살산, 젖산 및 아세트산 등이 생성 되어(21), 잡균에 의한 오염 방지로 저장성 향상에 도움을 줄 것으로 기대된다. Park과 Jang(22)의 복분자의 유산발효 와 생리활성 평가 연구에서 $37^{\circ} \mathrm{C}$ 에서 발효하였을 경우 산 생성능이 가장 높게 나타났으며, 최적 배양 시간은 72 시간 이 바람직하다고 보고하여 본 연구결과와 유사한 경향을 나타내었다.

Table 1. Change in viable cell count, $\mathrm{pH}$, and total acidity of blueberries fermented by Lactobacillus plantarum CGKW3

\begin{tabular}{cccc}
\hline $\begin{array}{c}\text { Fermentation time } \\
\text { (hr) }\end{array}$ & $\begin{array}{c}\text { Viable cell count } \\
\text { (log CFU/mL) }\end{array}$ & $\mathrm{pH}$ & $\begin{array}{c}\text { Total acidity } \\
(\%)\end{array}$ \\
\hline Unfermented & - & $4.19 \pm 0.01^{\mathrm{a}}$ & $0.12 \pm 0.01^{\mathrm{d}}$ \\
0 & $4.28 \pm 0.09^{\mathrm{cl}}$ & $3.56 \pm 0.02^{\mathrm{b}}$ & $0.12 \pm 0.00^{\mathrm{d}}$ \\
24 & $4.36 \pm 0.05^{\mathrm{c}}$ & $3.51 \pm 0.02^{\mathrm{c}}$ & $0.14 \pm 0.01^{\mathrm{c}}$ \\
48 & $5.28 \pm 0.14^{\mathrm{b}}$ & $3.42 \pm 0.01^{\mathrm{d}}$ & $0.16 \pm 0.02^{\mathrm{b}}$ \\
72 & $5.96 \pm 0.09^{\mathrm{a}}$ & $3.35 \pm 0.01^{\mathrm{e}}$ & $0.19 \pm 0.01^{\mathrm{a}}$ \\
96 & $5.92 \pm 0.11^{\mathrm{a}}$ & $3.29 \pm 0.01^{\mathrm{f}}$ & $0.21 \pm 0.02^{\mathrm{a}}$ \\
\hline
\end{tabular}

${ }^{1)}$ All values are expressed as mean $\pm \mathrm{SD}$ of triplicate determinations. Means within each column followed by the same letter are not significantly different $(p<0.05)$.

\section{총 안토시아닌 및 cyanidin-3-glucoside 함량}

안토시아닌은 수용성 색소로 기능성 측면에서 블루베리 의 품질을 판단 할 수 있는 중요한 지표성분이라 할 수 있으며(23), cyanidin-3-glucoside(C3G)는 안토시아닌 색소 중에서도 항산화력이 뛰어난 것으로 알려져 있어 노화억 제, 망막장애의 치료 및 시력개선 효과 등 다양한 생리활성 을 가지고 있다(24). 블루베리의 발효에 따른 배양 시간별 총 안토시아닌 및 $\mathrm{C} 3 \mathrm{G}$ 함량은 Table 2에 나타내었다. 블루 베리의 배양 시간별 총 안토시아닌 및 $\mathrm{C} 3 \mathrm{G}$ 함량은 배양 72 시간에서 각각 $100 \mathrm{~g}$ 당 $31.52 \mathrm{mg}$ 및 $5.41 \mathrm{mg}$ 을 나타내어 무발효 블루베리 $16.10 \mathrm{mg}$ 및 $2.21 \mathrm{mg}$ 에 비해 약 2배 높은 함량을 나타내었다. 따라서 생균수, 총 안토시아닌 및 $\mathrm{C} 3 \mathrm{G}$ 함량을 고려하였을 때 블루베리 최적 배양 시간은 72 시간 이 바람직하다고 판단되었다. Song 등(25)은 국내산 두 품 종 블루베리의 영양성분 및 항산화 활성 비교 연구에서 총 안토시아닌 함량이 $100 \mathrm{~g}$ 당 $18.1 \mathrm{mg}$ 및 $22.0 \mathrm{mg}$ 으로 본 연구의 무발효 블루베리와 유사한 경향을 나타내었으 며, 각기 다른 안토시아닌 함량은 재배지의 토양 및 기후특
성에 의해 영향을 받는 것으로 보고하였다. 또한 $\mathrm{Ryu}$ 와 Kwon(26)의 오디의 추출 공정에 따른 성분 변화 및 분말 과립차의 연구에서 젖산균 발효과정에 의해 안토시아닌 함량이 7.1배 증가하였다고 보고하여 본 연구결과와 유사 한 경향을 나타내었다.

Table 2. Change in total anthocyanin and cyanidin-3-glucoside contents of blueberries fermented by Lactobacillus plantarum CGKW3

\begin{tabular}{ccc}
\hline $\begin{array}{c}\text { Fermentation time } \\
(\mathrm{hr})\end{array}$ & $\begin{array}{c}\text { Total anthocyanin } \\
(\mathrm{mg} / 100 \mathrm{~g})\end{array}$ & $\begin{array}{c}\text { Cyanidin-3-glucoside } \\
(\mathrm{mg} / 100 \mathrm{~g})\end{array}$ \\
\hline Unfermented & $16.10 \pm 0.86^{\mathrm{e} 1)}$ & $2.21 \pm 0.02^{\mathrm{f}}$ \\
0 & $24.38 \pm 1.19^{\mathrm{d}}$ & $3.60 \pm 0.10^{\mathrm{e}}$ \\
24 & $25.72 \pm 0.73^{\mathrm{c}}$ & $3.73 \pm 0.03^{\mathrm{d}}$ \\
48 & $27.64 \pm 1.42^{\mathrm{b}}$ & $4.04 \pm 0.13^{\mathrm{c}}$ \\
72 & $31.52 \pm 0.36^{\mathrm{a}}$ & $5.41 \pm 0.09^{\mathrm{a}}$ \\
96 & $28.29 \pm 0.56^{\mathrm{b}}$ & $4.92 \pm 0.04^{\mathrm{b}}$ \\
\hline
\end{tabular}

${ }^{1)}$ All values are expressed as mean \pm SD of triplicate determinations. Means within each column followed by the same letter are not significantly different $(p<0.05)$.

\section{색도, 총 폴리페놀 및 총 플라보노이드 함량}

블루베리 무발효 및 발효물의 색도, 총 폴리페놀 및 총 플라보노이드는 Table 3에 나타내었다. L값 및 a값은 블루 베리 발효물에서 각각 40.26 및 14.55 를 나타내어 무발효 블루베리 44.70 및 16.296에 비해 낮게 나타났다. b값은 블루베리 발효물에서 5.28로 블루베리 무발효 4.07에 비해 높게 나타났으며, 발효 전 블루베리를 기준으로 본 $\triangle \mathrm{E}$ 값은 블루베리 발효 후 6.23 의 색 변화를 나타내었다. 이는 Lee와 Chae(27)의 적포도 주 발효 중 페놀류 추출 및 색도 변화에 관한 연구에서 적포도주의 색은 초기의 적자색에서 후 발효 가 지속되고 숙성 기간이 오래될수록 포도의 안토시아닌 색소가 새롭고 보다 안정한 다중합체로 전환됨에 따라 황갈 색의 색상으로 변한다고 보고하여 본 연구결과 유사한 경향 을 나타내었다.

총 폴리페놀 및 총 플라보노이드 함량은 블루베리 발효 물에서 $100 \mathrm{~g}$ 당 각각 $2.21 \mathrm{~g}$ 및 $0.91 \mathrm{~g}$ 을 나타내어 무발효 블루베리 $1.13 \mathrm{~g}$ 및 $0.49 \mathrm{~g}$ 에 비해 높은 함량을 나타내었다. Chae 등(28)은 효소처리와 유산균 배양에 의해 흑마늘의 총 폴리페놀 함량이 증가하였으며, Seo 등(29)은 꾸지뽕 열매를 L casei KCRZ 1121 및 L. plantarum ATCC 10830 유산균을 이용하여 발효한 다음 폴리페놀 함량이 약 $47 \%$ 증가하였다고 보고하여 본 연구결과와 유사한 경향을 나타 내었다. 이는 식물성 식품 속에 함유되어 있는 많은 생리활 성 물질 중 페놀류는 phenolic hydroxyl 그룹에 의해 거대 분자들과 결합하는 성질 및 2 가 금속이온과의 결합력으로 인하여 높은 항산화 효과를 가지는 것으로 알려져 있어(30), 블루베리 발효를 통해 증가된 폴리페놀 및 플라보노이드 물질 등에 의해 항산화 효과가 증진될 것으로 사료된다. 
Table 3. Hunter's color value, total polyphenol content, and total flavonoid content of blueberries fermented by Lactobacillus plantarum CGKW3

\begin{tabular}{|c|c|c|c|c|c|c|}
\hline \multirow{2}{*}{ Sample } & \multicolumn{4}{|c|}{ Hunter's color value } & \multirow{2}{*}{$\begin{array}{l}\text { Total polyphenol content } \\
(\mathrm{g} / 100 \mathrm{~g})\end{array}$} & \multirow{2}{*}{$\begin{array}{l}\text { Total flavonoid conten } \\
(\mathrm{g} / 100 \mathrm{~g})\end{array}$} \\
\hline & $\mathrm{L}$ & $\mathrm{a}$ & $\mathrm{b}$ & $\triangle \mathrm{E}$ & & \\
\hline Blueberry & $44.70 \pm 0.10^{1)}$ & $16.29 \pm 0.07$ & $4.07 \pm 0.04$ & - & $1.13 \pm 0.68$ & $0.49 \pm 0.09$ \\
\hline Fermented blueberry & $40.26 \pm 0.07$ & $14.55 \pm 0.04$ & $5.28 \pm 0.01$ & $6.23 \pm 0.12$ & $2.21 \pm 0.15$ & $0.91 \pm 0.22$ \\
\hline
\end{tabular}

${ }^{1)}$ All values are expressed as mean \pm SD of triplicate determinations.

\section{항산화활성}

블루베리 무발효 및 발효물의 항산화 활성은 DPPH, superoxide radical 소거활성 및 FRAP로 분석하였으며 Table 4에 나타내었다. DPPH 및 superoxide radical 소거활 성은 블루베리 발효물에서 각각 $30.74 \%$ 및 $52.76 \%$ 를 나타 내어 무발효 블루베리 $21.07 \%$ 및 $40.91 \%$ 에 비해 활성이 유의적으로 증가하는 것으로 나타났다. $\operatorname{Park}(31)$ 은 Lactobacillus sp. 균주를 이용한 오미자 발효특성 연구에서 발효 후 농도 의존적으로 활성이 증가한다고 보고하였으 며, Choi와 Shin(32)의 국산 블루베리 착즙액의 항산화 활성 연구에서 블루베리 착즙액의 항산화능은 플라보노이드와 폴리페놀 계열 성분에 의해 나타난다고 보고하였다.

FRAP 결과에서도 블루베리 발효물은 $256.42 \mu \mathrm{M}$ 을 나타 내어 무발효 블루베리 $191.52 \mu \mathrm{M}$ 에 비해 높은 항산화 활성 을 나타내었다. Kim 등(33)은 발효 공정을 통한 아로니아 추출물의 환원력 평가에서 유산균을 통한 발효를 실시함으 로서 무발효 추출물에 비해 더욱 증진 된 항산화 효능을 확인하였으며, Tosun 등(34)은 산딸기속(Rubus) 식물의 항 산화능은 총 페놀성 화합물과 함께 총 안토시아닌 함량도 밀접한 관계가 있다고 보고하였다. 이와 같이 유용성분의 함량이 높은 블루베리 발효물에서 항산화 활성이 높게 나타 난 것으로 사료된다.

\section{저장안정성}

블루베리 무발효 및 발효물의 저장기간에 따른 총 안토 시아닌 및 $\mathrm{C} 3 \mathrm{G}$ 함량의 감소율을 Fig. 1에 나타내었다. 저장 7 일 경과 후 총 안토시아닌 및 $\mathrm{C} 3 \mathrm{G}$ 함량 감소율은 블루베리 발효물에서 각각 $10.67 \%$ 및 $17.34 \%$ 를 나타내었으며, 저장 42일 이 후 블루베리 발효물은 각각 $48.03 \%$ 및 $38.71 \%$
감소하여 블루베리 무발효 감소율 $65.00 \%$ 및 $78.88 \%$ 에 비 해 총 안토시아닌 및 $\mathrm{C} 3 \mathrm{G}$ 함량이 낮게 감소하여 블루베리 발효물의 저장 안정성이 유의적으로 높음을 확인하였다. 무발효 블루베리는 $33.21 \%$ 및 $33.80 \%$ 의 감소율을 나타내 기 시작한 다음 지속적으로 감소하는 경향을 나타내었다. Park 등(35)은 유통 및 저장 온도에 따른 오디의 품질변화 연구에서 안토시아닌 함량이 저장 중 감소하는 것은 저장 중 호흡작용과 함께 노화과정이 진행되면서 색소의 안정성 에 영향을 미치는 인자들이 변화됨에 따라 안토시아닌이 점차 소실되었다고 보고하였다. Jeong 등(36)은 포도 발효 중 발효액의 생리활성 연구에서 안토시아닌이 포도가 숙성 됨에 따라 폴리페놀류와 결합하면서 안정화되어 적색을 오래 유지할 수 있게 된다고 보고하였다. 또한 JiménezAguilar 등(37)은 블루베리 농축액에 mesquite gum을 피복 물질로 사용하여 분무건조시 $25^{\circ} \mathrm{C}$ 에서 빛에 노출하여 저장 하였을 때, 총 안토시아닌 함량은 저장 4 주차 때 동결건조분 말 및 분무건조분말에서 각각 $65 \%$ 및 $24 \%$ 감소하였으며, 이는 부형제로 사용된 mesquite gum의 보호작용에 기인된 다고 보고하였다. 본 연구에서는 실온에서 빛에 노출하여 저장하였을 때, 총 안토시아닌 함량은 저장 4 주차 때 블루베 리 무발효 동결건조분말 및 발효물 동결건조분말에서 각각 $42.82 \%$ 및 $14.97 \%$ 감소하여 유산균을 이용한 블루베리 발 효시 부형제를 첨가한 분무건조분말(37)과 유사한 감소율 을 나타내어 높은 저장안정성을 나타냄을 확인하였다. 이 와 같이, 블루베리는 유산균 배양에 의해 $\mathrm{pH}$ 및 산도의 변화와 유용물질들의 증가 및 결합에 의해 안토시아닌 색소 의 저장안정성이 향상된 것으로 판단된다.

Table 4. DPPH radical scavenging activity, superoxide radical scavenging activity, and FRAP (ferric reducing antioxidant potential) of blueberries fermented by Lactobacillus plantarum CGKW3

\begin{tabular}{lccc}
\hline \multicolumn{1}{c}{ Sample } & $\begin{array}{c}\text { DPPH radical scavenging activity } \\
(1 \mathrm{mg} / \mathrm{mL}, \%)\end{array}$ & $\begin{array}{c}\text { Superoxide radical scavenging activity } \\
(1 \mathrm{mg} / \mathrm{mL}, \%)\end{array}$ & $\begin{array}{c}\text { FRAP } \\
\left(1 \mathrm{mg} / \mathrm{mL}, \mathrm{FeS} 0_{4}, \mu \mathrm{M}\right)\end{array}$ \\
\hline Blueberry & $21.07 \pm 0.71^{\mathrm{c} l)}$ & $40.91 \pm 1.97^{\mathrm{c}}$ & $191.52 \pm 9.13^{\mathrm{c}}$ \\
Fermented blueberry & $30.74 \pm 0.29^{\mathrm{b}}$ & $52.76 \pm 2.16^{\mathrm{b}}$ & $256.42 \pm 7.45^{\mathrm{b}}$ \\
${\text { Positive } \text { control }^{2)}}^{96.04 \pm 0.62^{\mathrm{a}}}$ & $92.21 \pm 2.58^{\mathrm{a}}$ & $1,767.20 \pm 10.01^{\mathrm{a}}$ \\
\hline
\end{tabular}

\footnotetext{
${ }^{1)}$ All values are expressed as mean $\pm \mathrm{SD}$ of triplicate determinations. Means within each column followed by the same letter are not significantly different $(\mathrm{p}<0.05)$.

${ }^{2)}$ Positive control : ascorbic acid (DPPH radical scavenging activity and FRAP) and catechin (superoxide radical scavenging activity) solution were measured at $1 \mathrm{mg} / \mathrm{mL}$, respectively.
} 
(A)

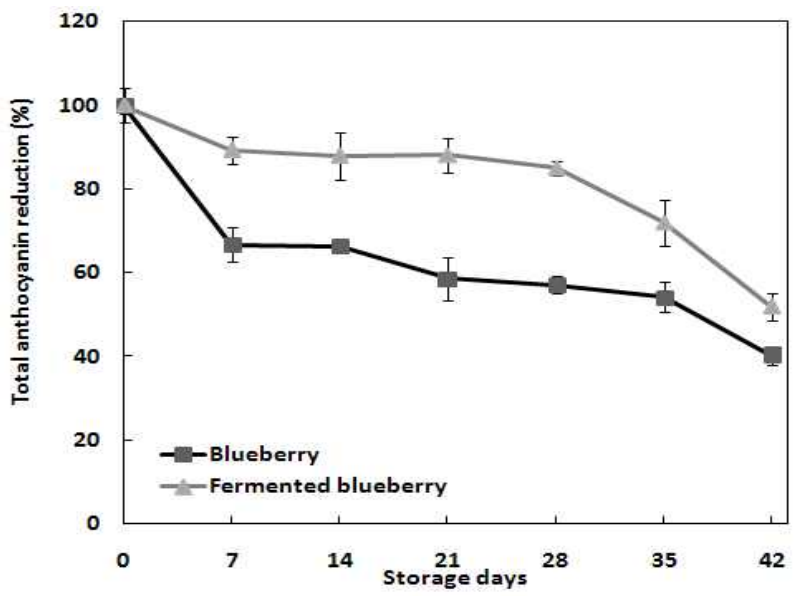

(B)

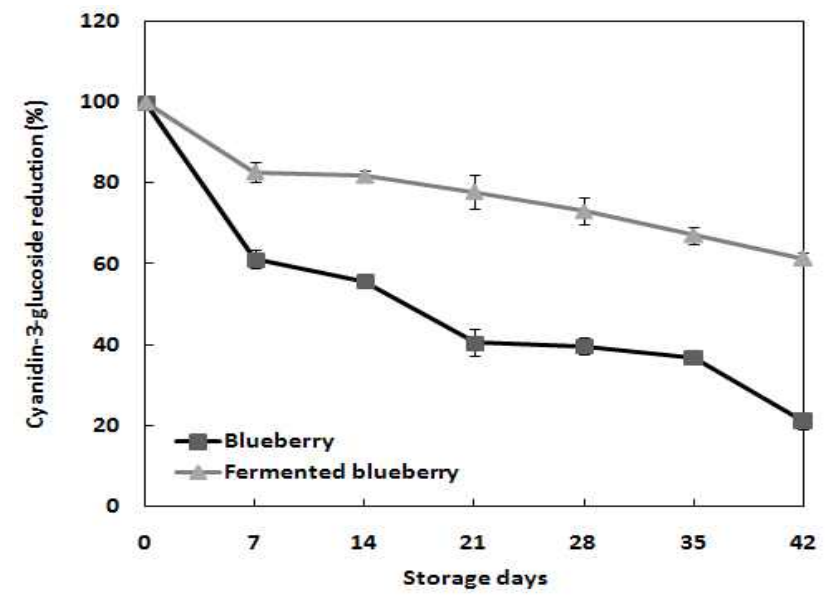

Fig. 1. Changes in total anthocyanin and cyanidin-3-glucoside content of fermented blueberry during storage (42 days) at room temperature.

All values are expressed as mean \pm SD of triplicate determinations.

\section{요 약}

본 연구에서는 다양한 생리활성을 가진다고 알려져 있는 블루베리의 식품 산업에서의 이용 증대를 목적으로 블루베 리 유산균 발효물을 제조하였으며 이화학적 특성 및 저장 안정성을 조사하였다. 생균수는 발효 72시간에서 가장 높 은 $5.96 \log \mathrm{CFU} / \mathrm{mL}$ 를 나타내었으며, $\mathrm{pH}$ 및 산도는 각각 발효 시간 경과에 따라 유의적으로 감소 및 증가하였다. 총 안토시아닌 및 cyanidin-3-glucoside(C3G) 함량은 발효 72시간에서 각각 $100 \mathrm{~g}$ 당 $31.52 \mathrm{mg}$ 및 $5.41 \mathrm{mg}$ 으로 가장 높은 함량을 나타내어 생균수, 총 안토시아닌 및 $\mathrm{C} 3 \mathrm{G}$ 함량 을 고려하여 72시간을 최적 발효 구간으로 선정하였다. 블 루베리 발효물의 L값 및 $\mathrm{a}$ 값은 발효 후 감소하고, $\mathrm{b}$ 값 및 $\triangle \mathrm{E}$ 값은 증가하였으며, 총 폴리페놀 및 총 플라보노이드
함량은 $100 \mathrm{~g}$ 당 $2.21 \mathrm{~g}$ 및 $0.91 \mathrm{~g}$ 으로 발효 전에 비해 높게 나타났다. 항산화활성은 DPPH 및 superoxide radical 소거 활성에서는 블루베리 발효물에서 각각 $30.74 \%$ 및 $52.76 \%$ 를 나타내어 무발효물 보다 높은 소거활성을 나타내었으 며, FRAP에서도 $256.42 \mu \mathrm{M}$ 을 나타내어 블루베리 발효물에 서 높은 항산화 활성을 나타내었다. 블루베리 발효물의 저 장안정성은 총 안토시아닌 및 $\mathrm{C} 3 \mathrm{G}$ 함량의 감소율로 확인하 였는데, 42 일 경과 후 $48.03 \%$ 및 $38.71 \%$ 감소하여 무발효물 에 비해 우수하였다. 따라서, 블루베리 발효물은 유용물질 증가로 인한 안정성 향상을 통해 식품가공 산업에서의 활용 증진이 기대된다.

\section{감사의 글}

본 논문은 2015학년도 대구가톨릭대학교 교내연구비 지 원에 의한 것으로 감사드립니다.

\section{References}

1. Park JS, Bae JO, Chung BW, Jung MY, Choi DS (2011) Degradation kinetics of anthocyanin pigment solutions from purple-fleshed sweet potato cultivars. Korean J Food Nutr, 24, 559-566

2. Janna OA, Khairul AK, Maziah M (2007) Anthocyanin stability studies in Tibouchina semidecandra L. Food Chem, 101, 1640-1646

3. Macheix JJ, Fleuriet A, Billot J (1990) The main phenolics of fruit. In: Fruit Phenolics. CRC Press, Boca Raton, Florida, USA, p 1-104

4. Chung KW, Joo YH, Lee DJ (2004) Content and color difference of anthocyanin by different storage periods in seed coats of black soybean [Glycine max (L.) Merr.]. Korean J Int Agri, 16, 196-199

5. Cho SB, Kim HJ, Yoon JI, Chun HS (2003) Kinetic study on the color deterioration of crude anthocyanin extract from Schizandra fruit. Korea J Food Sci Technol, 35, 23-27

6. Wang D, Zou T, Yang Y, Yan X, Ling W (2011) Cyanidin-3-O- $\beta$-glucoside with the aid of its metabolite protocatechuic acid, reduces monocyte infiltration in apolipoprotein E-deficient mice. Biochem Pharmacol, 82, 713-719

7. Sun C, Zheng $\mathrm{Y}$, Chen $\mathrm{Q}$, Tang $\mathrm{X}$, Jiang $\mathrm{M}$, Zhang J, Li X, Chen K (2012) Purification and anti-tumor activity of cyanidin-3-O-glucoside from Chinese bayberry fruit. 
Food Chem, 131, 1287-1294

8. Westwood MN (1993) Temperate-zone pomology. Timber Press, Portland, OR, USA, p 100-101

9. Jeong HR, Jo YN, Jeong JH, Kim HJ, Heo HJ (2012) Nutritional composition and in vitro antioxidant activities of blueberry (Vaccinium asheii) leaf. Korean J Food Preserv, 19, 604-610

10. Lee JG, Lee BY (2007) Effect of media composition on growth and rooting of highbush blueberry cuttings. Korean J Hort Sci Technol, 25, 355-359

11. Su MS, Chien PJ (2007) Antioxidant activity, anthocyanins and phenolics of rabbiteye blueberry (Vaccinium asher) fluid products as affected by fermentation. Food Chem, 104, 182-187

12. Reyes LF, Cisneros-Zevallos L (2007) Degradation kinetics and colour of anthocyanins in aqueous extracts of purple-and red-flesh potatoes (Solanum tuberosum L.). Food Chem, 100, 885-894

13. Kim JH, Lee WJ, Cho YW, Kim KY (2009) Storage-life and palatability extension of Betula platyphylla sap using lactic acid bacteria fermentation. J Korean Soc Food Sci Nutr, 38, 787-794

14. Lee J, Dutst RW, Wrolstad RE (2005) Determination of total monomeric anthocyanin pigment content of fruit juices, beverages, natural colorants, and wines by the $\mathrm{pH}$ differential method : collaborative Study. J AOAC Int, 88, 1269-1278

15. Singleton VL, Rossi JA (1965) Colorimetry of total phenolics with phosphomolybdic-phosphotungstic acid reagents. Am J Enol Viticult, 16, 144-158

16. Davis WB (1947) Determination of flavonones in citrus fruits. Anal Chem, 19, 476

17. Blois MS (1958) Antioxidant determinations by the use of a stable free radical. Nature, 1199-1200

18. Morimitsu N, Appaji Rao N, Yagi K (1972) The occurrence of superoxide anion in the reaction of reduced phenazine methosulfate and molecular oxygen. Biochem Biophys Res Commun, 46, 849-854

19. Benzie IFF, Strain JJ (1996) The ferric reducing ability of plasma (FRAP) as a measure of "antioxidant power" : the FRAP assay. Anal Biochem, 239, 70-76

20. Kurmann JA, Rasic JL (1991) The health potential of products containing bifidobacteria. In: Therapeutic properties of fermented milks, Robinson RK (Editor), Elsevier Applied Food Science Series, London, England, p $117-158$

21. Kim GH, Bae EK (1999) Lactic acid bacteria for the preservation of fruit and vegetable. J Korean Postharvest Sci Technol, 6, 245-254

22. Park YS, Chang HG (2003) Lactic acid fermentation and biological activities of Rubus coreanus. J Korean Soc Agric Chem Biotechnol, 46, 367-375

23. Bagchi D, Sen CK, Bagchi M, Atalay M (2004) Antiangiogenic, antioxidant, and anticarcinogenic properties of a novel anthocyanin rich berry extract formula. Biochem, 69, 75-80

24. Kim HB (2013) Processing method of mulberry fruit juice improved C3G stability. J Seric Entomol Sci, 51, 159-163

25. Song HN, Park MS, Youn HS, Park SJ, Hogstrand C (2014) Nutritional compositions and antioxidative activities of two blueberry varieties cultivated in South Korea. Korean J Food Preserv, 21, 790-798

26. Ryu IH, Kwon TO (2012) Sensory characteristics of granular tea and the components of mulberry fruit extracts by different extraction process. Korean J Medicinal Corp Sci, 20, 331-338

27. Lee JY, Chae SK (2010) Studies on the changes in the extraction of phenolics and color characteristics by the enzyme treatment of red grape (Muscat Bailey A) wine during fermentation. Korean J Food Nutr, 3, 324-331

28. Chae HJ, Park DI, Lee SC, Oh CH, Oh NS, Kim DC, Won SI, In MJ (2011) Improvement of antioxidative activity by enzyme treatment and lactic acid bacteria cultivation in black garlic. J Korean Soc Food Sci Nutr, 40, 660-664

29. Seo MJ, Kang BW, Park JU, Kim MJ, Lee HH, Kim $\mathrm{NH}$, Kim KH, Rhu EJ, Jeong YK (2013) Effect of fermented Cudrania tricuspidata fruit extracts on the generation of the cytokines in mouse spleen cells. J Life Sci, 23, 682-688

30. Kwak JH, Choi GN, Park JH, Kim JH, Jeong HR, Jeong $\mathrm{CH}$, Heo HJ (2010) Antioxidant and neuronal cell protective effect of purple sweet potato extract. J Agric Life Sci, 44, 57-66

31. Park SC (2014) Characteristics of fermented Omija (Schizandra chinensis Baillon) sugar treatment extracts by Lactobacillus sp. Korean J Microbiol, 50, 60-66

32. Choi MH, Shin HJ (2015) Anti-oxidative and anti-menogenesis effects of blueberry extract. Korean J Aesthet Cosmetol, 13, 261-266

33. Kim NY, Lee YD, Cho SC, Shin YC, Lee HY (2014) Enhancement of anti-inflammation effect by fermentation process in Aronia melanocarpa (Michx.) elliot extract. Korean J Medicinal Crop Sci, 22, 475-482 
34. Tosan M, Ercisli S, Karlidag H, Sengul M (2009) Characterization of red raspberry (Rubus idaeus L.) genotypes for their physicochemical properties. J Food Sci, 74, 575-579

35. Park JH, Choi JH, Hong SI, Jeong MC, Kim DM (2013) Changes in quality of mulberry depending on distribution and storage temperature. Korean J Food Preserv, 20, $141-150$

36. Jeong SH, Chang EH, Hur YY, Jeong SM, Nam JC,
Koh SW, Choi IM (2015) Phenolic compounds of must and wine supplemented with muscat bailey a grape fruit stem. Korean J Food Preserv, 22, 91-99

37. Jiménez-Aguilar DM, Ortega-Regules AE, LozadaRamírez JD, Pérez-Pérez MCI, Vernon-Carter EJ, Welti-Chanes J (2011) Color and chemical stability of spray-dried blueberry extract using mesquite gum as wall material. J Food Compos Anal, 24, 889-894 